\title{
Multiplex PCR assay for ureC and 16S rRNA genes clearly discriminates between both subspecies of Photobacterium damselae
}

\author{
C. R. Osorio*, A. E. Toranzo, J. L. Romalde, J. L. Barja \\ Departamento de Microbiología y Parasitología, Facultad de Biología and Instituto de Acuicultura, Universidad de Santiago, \\ 15706, Santiago de Compostela, Spain
}

\begin{abstract}
A multiplex-PCR approach, employing 2 primer pairs directed to internal regions of the $16 S$ rRNA and ure $C$ genes, was utilized to analyze a collection of Photobacterium danselae strains, including 25 isolates of subspecies piscicida and 15 isolates of subspecies damselae. With this procedure, all the $P$. damselae subsp. damselae strains yielded 2 amplification products, one of 267 bp and the other of $448 \mathrm{bp}$, corresponding to internal fragments of the $16 \mathrm{~S}$ rRNA and ureC genes, respectively. However, $P$. damselae subsp. piscicida isolates only showed the PCR product of 267 bp (16S rRNA fragment), indicating the absence of the urease gene in its genome. We have constructed a DNA probe directed to an internal region of the ure $C$ gene, and corroborated by dot blot hybridization that the $P$. damselae subsp. piscicida lacks this gene, whereas it is present in the subspecies damselae. This constitutes the first successful discrimination between both subspecies using a PCR procedure, which could become a useful tool for diagnosis of pasteurellosis in the field. In addition, since these 2 subspecies have been shown to share nearly the same rrn operon sequence, our results provided evidence that one of the steps in the $P$. damselae speciation proccess included gain/loss events associated with the ure operon
\end{abstract}

KEY WORDS: Multiplex-PCR - Photobacterium damselae $\cdot$ ureC gene - 16S rRNA gene - Subspecies discrimination

\section{INTRODUCTION}

Pasteurellosis or pseudotuberculosis is a fish disease that causes enormous losses in fish aquaculture production worldwide (Kusuda \& Salati 1993, Magariños et al. 1996, Romalde \& Magariños 1997). The causative agent of fish pasteurellosis is the Gram-negative bacterium Photobacterium damselae subsp. piscicida, formerly named Pasteurella piscicida (Snieszko et al. 1964). Though the taxonomic position of this fish pathogen remained unclear for decades, preliminary phylogenetic studies (Gauthier et al. 1995) based on 16S rRNA sequencing conducted in 2 strains of Pasteurella piscicida showed that this species is closely related to members of the genus Photobacterium, and that it shares its species epithet with Photobacterium

\footnotetext{
·E-mail: mpaetjlb@usc.es
}

damselae subsp. damselae (formerly Vibrio damsela), known as a pathogen for poikilotherms and mammals. More recent studies on this ribosomal gene, from an extensive number of strains from different geographical and host origin, clearly confirmed that both bacteria share the same sequence in their 16S rRNA gene and that they definitively belong to the genus Photobacterium (Osorio 1998, Osorio et al. 1999), Photobacterium histaminum being the most closely related species with a $98.1 \%$ similarity with all the P. damselae isolates analyzed.

Initial attempts to detect the causative agent of fish pasteurellosis using molecular tools were based upon a short DNA sequence obtained from a Photobacterium damselae subsp. piscicida genomic library which served as a DNA probe for the detection of the pathogen (Aoki et al. 1995, Zhao \& Aoki 1989). Subsequently, the same DNA fragment was employed as the basis for the design of oligonucleotide primers for the PCR-based 
detection of $P$. damselae subsp. piscicida. Nevertheless, these approaches proved to be inconvenient for the diagnosis of fish pasteurellosis since it has been demonstrated that this short target DNA sequence is also present in some $P$. damselae subsp. damselae isolates (Osorio 1998). Moreover, these described molecular tools were assayed with only Japanese isolates, and no European strains were included.

In addition, some attempts have been made to detect Photobacterium damselae subsp. piscicida by PCR using plasmid sequences as a target (Aoki et al. 1997). Unfortunately, these plasmid-based primers were only tested with Japanese and American isolates, but not with any European isolate. In this regard, this approach would not be suitable for detection of most of the European isolates, since the plasmid content has proved to be very different depending on the geographical origin of subsp. piscicida strains (Magarinos et aì. 1992, 1996),

Although the information obtained with the $16 S$ rRNA gene sequencing of a great number of worldwide isolates from both subspecies of Photobacterium damselae allowed the design of a species-specific PCR-based detection method (Osorio et al. 1999), the design of a subspecies-specific molecular detection method has been hampered by the high degree of overall genomic homology between both subspecies. Therefore, identification of differential gene occurrence between the 2 subspecies of $P$. damselae was required. For this reason, we focused on the main phenotypical traits in which the subspecies differ, such as motility, nitrate reduction, urease and haemolysin production (Fouz et al. 1992, Magariños et al. 1992). This strategy has proved to be useful for taxonomical and discriminative purposes in other bacterial groups (Dasen et al. 1998, Lucchini et al. 1998).

Since the ability to hydrolyze urea seems to be a common feature in all the Photobacterium damselae subsp. damselae strains, but it is not found in any subsp. piscicida isolate (Magariños et al. 1996), in this study we developed a multiplex PCR assay using $P$. damselae-specific $16 \mathrm{~S}$ rRNA gene-directed primers in conjunction with others designed on the basis of the partial ureC gene sequence. This constitutes the first successful approach to discriminating between subsp damselae and subsp piscicida by means of PCR, accounting for one of the few insights into the genetic divergence between these taxa achieved so far

\section{MATERIAL AND METHODS}

Bacterial strains. A total of 25 strains of Photobacterium damselae subsp. piscicida isolated from different fish species in Europe, Japan and USA were used in this study. Since $P$. damselae subsp. damselae is a common pathogen for both poikilotherm and homoiotherm animals, the source of the 16 strains used comprised fish, shellfish, mammals (including humans) and seawater (Table 1). For comparative purposes, the $P$. histaminum strain JCM 8968 was also included in the present study (Okuzumi et al. 1994).

All the bacterial strains were routinely cultured on BHA (Brain Heart Infusion Agar) (Pronadisa, Madrid, Spain) supplemented with $1 \% \mathrm{NaCl}$ at $25^{\circ} \mathrm{C}$ for 24 to $48 \mathrm{~h}$. The taxonomical position of the isolates was confirmed following conventional plate and tube tests procedures described elsewhere (Fouz et al. 1992, Magariños et al. 1992), as well as by API-20E systems, obtaining the typical profile numbers 2005004 (Photobacterium damselae subsp. piscicida) and 2015004 ( $P$. damselae subsp. damselae).

DNA extraction. Genomic DNA was extracted following a modification to the method described by Lawson et al. (1989). Briefly, bacterial cells were resuspended in $500 \mu \mathrm{l}$ of TES buffer, and incubated at $37^{\circ} \mathrm{C}$ for 30 min after addition of $5 \mu$ of lysozyme $(10 \mathrm{mg}$ $\mathrm{ml}^{-1}$ ). Then, $5 \mu \mathrm{l}$ each of Proteinase K (Sigma, Madrid, Spain) (10 $\mathrm{mg} \mathrm{ml}^{-1}$ ) and RNase (Sigma) (10 $\mathrm{mg} \mathrm{ml}^{-1}$ ) were added and the solution was incubated for $1 \mathrm{~h}$ at $65^{\circ} \mathrm{C}$. After addition of $50 \mu \mathrm{l}$ of $20 \%$ SDS, tubes were returned immediately to the $65^{\circ} \mathrm{C}$ water-bath for a further $10 \mathrm{~min}$. After cell lysis, a phenol/chloroform (Amresco, Barcelona, Spain) extraction was carried out. DNA was precipitated with cold ethanol $\left(-20^{\circ} \mathrm{C}\right)$, centrifuged $(15000 \times g)$ and the DNA pellet air-dried and resuspended in 50 to $100 \mu$ sterile water. DNA quality and concentration was measured by loading a $5 \mathrm{ul}$ sample onto a $1 \%$ agarose gel or, alternatively, by spectrophotometrical measurement at $260 \mathrm{~nm}$.

Oligonucleotide design for ureC gene amplification. Nucleotide sequence of partial ureC gene from Photobacterium damselae subsp. damselae was retrieved from GenBank database with accession number U40071. A forward primer, Ure-5' (20-mer 5'-TCCGGAATAGGTAAAGCGGG-3'), and a reverse primer, Ure-3' (22-mer 5' -CTTGAATATCCATCTCATCTGC$\left.3^{\prime}\right)$, were designed flanking a $448 \mathrm{bp}$-long stretch of the ure C gene, as it is shown in Fig. 1.

A forward primer, Car1 18-mer 5'-GCTTGAAGAGATTCGAGT-3') (positions 1016 to 1033 in Escherichia coli $16 \mathrm{~S}$ rRNA gene), and a reverse primer, Car2 (18-mer 5'-CACCTCGCGGTCTTGCTG-3') (positions 1266 to 1283), flanking a 267 bp fragment of the $16 \mathrm{~S}$ gene of strain ATCC 29690 of Photobacterium damselae subsp. piscicida (GenBank accession number Y18496) (Osorio et al. 1999) were used in conjunction with Ure-5' and Ure-3' in a multiplex PCR reaction. PCR amplifications were performed in a DNA thermal cycler (Eppendorf, Hamburg, Germany). A typical 
Table 1. Photobacterium strains used in this study

\begin{tabular}{|c|c|c|c|c|}
\hline Strain ${ }^{a}$ & Origin & Country & $\begin{array}{l}\text { Urease } \\
\text { activity }\end{array}$ & $\begin{array}{l}\text { Presence of } \\
\text { ureC gene }\end{array}$ \\
\hline \multicolumn{5}{|c|}{ P. damselae subsp. piscicida } \\
\hline DI 21 & Gilthead seabream & Spain & - & - \\
\hline DI 91 & Gilthead seabream & Spain & - & - \\
\hline $\mathrm{Cl}$ & Gilthead seabream & Spain & - & - \\
\hline $\mathrm{C} 2$ & Gilthead seabream & Spain & - & - \\
\hline R 46 & Gilthead seabream & Spain & - & - \\
\hline DS 11 & Gilthead seabream & Spain & - & - \\
\hline B 21 & Seabass & Spain & - & - \\
\hline B 51 & Seabass & Spain & - & - \\
\hline 619.1 & Gilthead seabream & Partugal & - & - \\
\hline 693.2 & Gilthead seabream & Portugal & - & - \\
\hline 666.1 & Seabass & Portugal & - & - \\
\hline 10831 & Seabass & France & - & - \\
\hline IT-1 & Gilthead seabream & Italy & - & - \\
\hline$\Gamma-2$ & Gilthead seabream & Italy & - & - \\
\hline $069 \mathrm{~A}$ & Gilthead seabream & Greece & - & - \\
\hline $\mathrm{O} 69 \mathrm{E}$ & Gilthead seabream & Greece & - & - \\
\hline ATLIT 2 & Seabass hybrid & Israel & - & - \\
\hline 2101 & Seabass hybrid & Israel & - & - \\
\hline MP-7801 & Yellowtail & Japan & - & - \\
\hline EPOY-8803-II & Red grouper & Japan & - & - \\
\hline P3333 & Yellowtail & Japan & - & - \\
\hline MZS 8001 & Yellowtail & Japan & - & - \\
\hline P3335 & Yellowtail & Japan & - & - \\
\hline ATCC 29690 & Yellowtail & Japan & -- & - \\
\hline ATCC 17911 & White perch & USA & - & - \\
\hline \multicolumn{5}{|c|}{ P. damselae subsp. damselae } \\
\hline RG -91 & Turbot & Spain & + & + \\
\hline RG-153 & Turbot & Spain & + & + \\
\hline RG-214 & Turbot & Spain & + & + \\
\hline $\mathrm{RM}-71$ & Turbot & Spain & + & + \\
\hline LD-07 & Gilthead seabream & Spain & + & + \\
\hline 340 & Seawater & Spain & + & + \\
\hline 309 & Mussel & Spain & + & + \\
\hline 158 & European eel & Belgium & + & + \\
\hline 162 & European eel & Belgium & + & + \\
\hline PG 801 & Shrimp & Taiwan & + & + \\
\hline J3G 801 & Shrimp & Taiwan & + & + \\
\hline 192 & Dolphin & USA & + & + \\
\hline 238 & Dolphin & USA & + & + \\
\hline ATCC 33539 & Damselfish & USA & + & + \\
\hline ATCC 35083 & Brown shark & USA & + & + \\
\hline CDC $2227-81$ & Human & USA & + & + \\
\hline \multicolumn{5}{|l|}{ P. histaminum } \\
\hline JCM 8968 & Labracoglossid fish & Japan & + & + \\
\hline \multicolumn{5}{|c|}{$\begin{array}{l}\text { "ATCC, American Type Culture Collection; CDC, Center for Diseases } \\
\text { Control; JCM, Japan Collection of Microorganisms } \\
\text { bUrease activity determined by tube and API-20E tests } \\
\text { 'Presence of ureC gene demonstrated by multiplex PCR (see Fig. 2) }\end{array}$} \\
\hline
\end{tabular}

conditions were: $95^{\circ} \mathrm{C}$ for 4 min followed by 30 cycles at $95^{\circ} \mathrm{C}$ for $1 \mathrm{~min}, 60^{\circ} \mathrm{C}$ for $1 \mathrm{~min}$, and $72^{\circ} \mathrm{C}$ for $40 \mathrm{~s}$. A final extension step of $5 \mathrm{~min}$ at $72^{\circ} \mathrm{C}$ was carried out. Amplification products were analysed on $1 \%(w / v)$ agarose gels with TAE $10.04 \mathrm{M}$ Tris-acetate, $1 \mathrm{mM}$ EDTA) electrophoresis buffer, and were visualized on a UV transilluminator after staining with ethidium bromide. A 100 bp DNA ladder (Bio-Rad, Madrid, Spain) was included as a molecular weight marker.

ureC DNA probe synthesis and labelling. The DNA probe for the partial ureC gene was synthesized by PCR amplification of the 448 bp urec fragment flanked by primers Ure-5' and Ure-3' (Fig, 1). PCR conditions were as described above for PCR detection of the ureC gene. The DNA probe was digoxigenin-labelled using a nucleotide mix from the DIG DNA labelling and detection kit (Boehringer Mannheim, Barcelona, Spain) containing $1 \mathrm{mM}$ each of dATP, dGTP and dCTP, $0.65 \mathrm{mM}$ dTTP and $0.35 \mathrm{mM}$ DIGlabelled dUTP. For a final $100 \mu \mathrm{l}$ PCR reaction $20 \mu$ l of this nucleotide mix were added, so that the final concentration was $200 \mu \mathrm{M}$ of each dNTP.

After PCR synthesis, probe DNA was purified as follows: to $100 \mu \mathrm{l}$ of probe solution, $12.5 \mu \mathrm{l}$ of $4 \mathrm{M} \mathrm{LiCl}$ and $375 \mu \mathrm{l}$ absolute ethanol $\left(-20^{\circ} \mathrm{C}\right)$ were added, and samples were incubated at $-70^{\circ} \mathrm{C}$ for $30 \mathrm{~min}$. Then, tubes were centrifuged at $13000 \mathrm{rpm}$ (15000 $\times g)$ for $15 \mathrm{~min}$ and subsequently washed with $200 \mu \mathrm{l}$ of $70 \%$ ethanol. Samples were dried using a Speedvac apparatus (Savant, New York, USA). The DNA pellet was resuspended in approximately $50 \mu$ l distilled water and its concentration was spectrophotometrically measured at $260 \mathrm{~nm}$.

'Dot-blot' hybridization with ureC gene DNA probe. The ureC DNA probe was used to carry out a hybridization directly onto purified Photobacterium damselae genomic DNA. DNA samples were diluted in a final volume of $50 \mu \mathrm{l}$ in TE buffer so that each sample contained approximately 200 to 400 ng DNA. Diluted samples were boiled for 5 min to denature double-stranded chromosomal DNA and immediately transferred

reaction mixture $(100 \mu \mathrm{l})$ consisted of $160 \mathrm{pmol}$ of each primer, $2 \mathrm{U}$ of Taq polymerase (Perkin Elmer, Madrid, Spain), $1 \times$ Taq polymerase buffer (Perkin Elmer), $2 \mathrm{mM} \mathrm{MgCl}_{2}, 200 \mu \mathrm{M}$ of each deoxynucleoside triphosphate, and $100 \mathrm{ng}$ of template DNA. The amplification onto a nylon membrane $(0.45 \mu \mathrm{m}$ pore size, Boehringer Mannheim), previously activated with $2 \times$ SSC, using a Minifold II apparatus (Schleicher \& Schuell, Dassel, Germany). Transferred DNA was fixed to the nylon with UV light for $2 \mathrm{~min}$ in a Ultraviolet Crosslinker 


\begin{tabular}{|c|c|c|c|c|c|}
\hline 1 & CGTATALCCE & GAMTAGTIAA & AGCGGGTAAC & CCAGACGTCC & AGCCTAATGT \\
\hline 51 & TGATATTGTT & ATCGGTCCCG & GTACAGAAGT & TGTGGCAGGC & GAAGGCAAGA \\
\hline 101 & TCGTAACAGC & TGGAGGAATC & GATACTCACA & TTCATTTTAT & CTGTCCTCAA \\
\hline 151 & CAAGCCGAAG & AAGGATTATG & TTCTGGCTTA & ACAACCTTTA & TCGGTGGCGG \\
\hline 201 & AACCGGTCCA & GTGGCGGGTT & CCAATGCAAC & AACCGTGACA & CCAGGGC \\
\hline 251 & GGAATATGTC & ACGAATGCTG & GAAGCCGTTG & ATGACTTACC & TATTAATGTG \\
\hline 301 & GGTTTATTTG & GTAAAGGTTG & TGTCAGTAAA & CCAGAAGCAT & TACGAGAGCA \\
\hline 351 & AATTGAAGCT & GGAGCTGTTG & GTTTAAAACT & GCATGAAGAT & TGGGGTGCX \\
\hline 401 & $\operatorname{cGcccs}$ & TATTA & TGTATGAATG & TGGCAGATGA & GATGGATATW \\
\hline 451 & CAAETI & $\mathrm{TC}$ & & & \\
\hline
\end{tabular}

Fig. 1. Partial ure $C$ gene sequence of Photobacterium damselae subsp. damselae (GenBank, accession number U40071). Target sites for Ure-5' and Ure-3' primers are highlighted. ureCtargeted probe was constructed by PCR amplification using these primers and digoxigenin-labelled dUTP
(Amersham Life Science, Barcelona, Spain). After being dried at $60^{\circ} \mathrm{C}$ in a oven, the membrane was kept at $4^{\circ} \mathrm{C}$ until hybridization was carried out.

Prehybridization $\left(68^{\circ} \mathrm{C}\right.$ for $\left.1 \mathrm{~h}\right)$ and hybridization $\left(56^{\circ} \mathrm{C}\right.$ for $\left.14 \mathrm{~h}\right)$ were performed in hybridization solution containing $5 \times \mathrm{SSC}$, blocking reagent $(1 \% \mathrm{w} / \mathrm{v}$, Boehringer Mannheim), $0.1 \%$ (w/v) sarcosyl, and $0.02 \%(\mathrm{w} / \mathrm{v})$ SDS. For the hybridization, $1 \mu \mathrm{g}$ of the labelled DNA probe was added to the hybridization buffer. After hybridization, nylon membranes were washed twice at room temperature in $2 \times \mathrm{SSC}, \quad 0.1 \%(\mathrm{w} / \mathrm{v})$ SDS and twice in $1 \times \mathrm{SSC}, 0.1 \% \mathrm{SDS}$ at $68^{\circ} \mathrm{C}$. Then, membranes were blocked and incubated with the anti-digoxigenin-alkaline phosphatase conjugate, and positive hybridizations were visualized colorimetrically using the DIG DNA detection kit (Boehringer Mannheim), following the manufacturer's recommendations.

\section{RESULTS}

A pair of $16 \mathrm{~S}$ rRNA gene-based PCR primers, namely CAR-1 and CAR-2, were previously designed (Osorio et al. 1999) for the specific detection of any Photobacterium damselae isolate. However, a subspecies specific gene was needed in order to design subspecies-specific primers that could discriminate between $P$. damselae subsp. piscicida and subsp. damselae. In this sense, another set of primers directed toward the urease gene were devised in this work, in order to develop a multiplex PCR assay which enables such discrimination.

Using this multiplex PCR assay, with 16S rRNA gene and ureC gene binding primers, all the Photobacterium damselae subsp. damselae strains used in the present study, regardless of their geographical ori- gin and source of isolation, yielded 2 amplification products of 267 and 448 bp (corresponding to an internal fragment of the 16S rRNA gene and one of the ure $C$ gene, respectively). In the same assay, all the $P$. damselae subsp. piscicida strains showed amplification of the 267 bp 16 S rRNA gene fragment, but no amplification of partial urease gene occurred (Table 1). Fig. 2 shows these differences in the multiplex PCR patterns for the strains of the 2 subspecies of $P$. damselae included in this study.
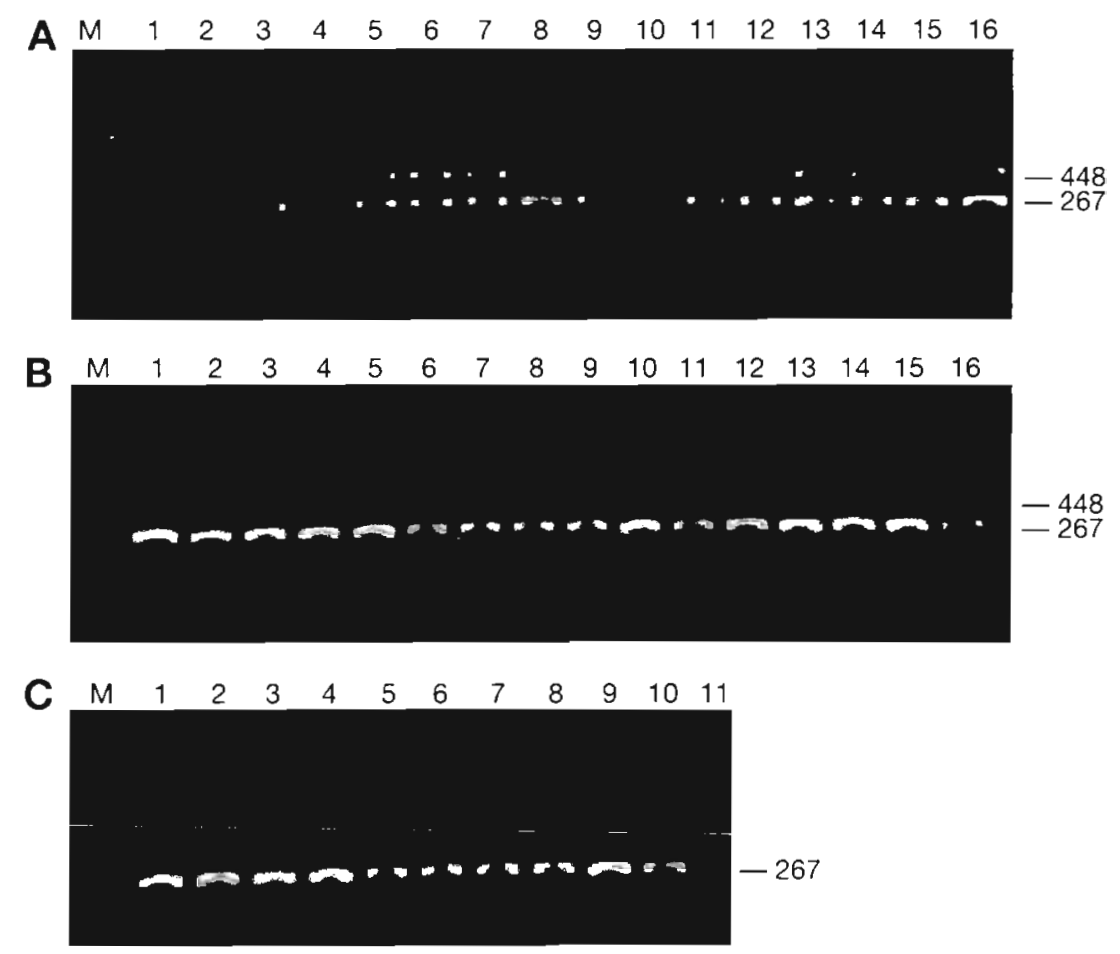

Fig. 2. Agarose electrophoresis of the multiplex-PCR products obtained for the different Photobacterium strains studied. Lanes: $M$, molecular weight marker 100 bp Molecular Ruler (Bio-Rad); (A) 1 to 16, P. damselae subsp. damselae strains; (B) 1, P. histaminum isolate; 2 to $16, P$. damselae subsp. piscicida strains; (C) 1 to $10, P$. damselae subsp. piscida strains; 11 , negative control (no DNA). Numbers on the right indicate the size of the amplification products, corresponding to the 448 and $267 \mathrm{bp}$ internal fragments of the ure $C$ and $16 \mathrm{~S}$ rRNA genes, respectively 


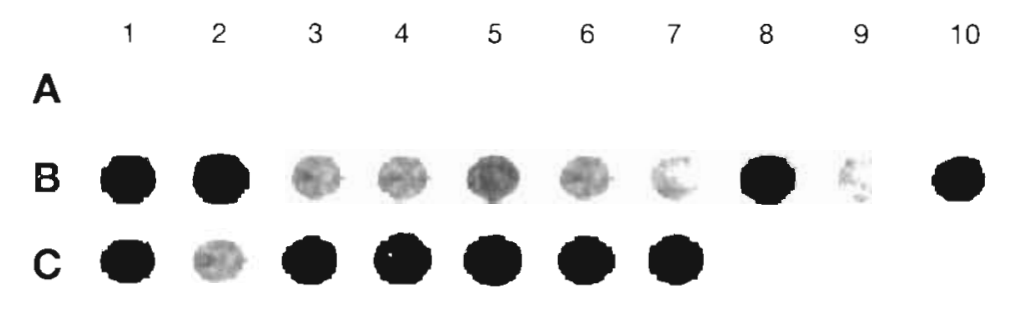

Fig. 3. Hybridization of the different Photobacterium strains with the ureC-targeted DNA probe. Genomic DNA (200 to 400 ng) was blotted onto nylon and membranes were exposed to the digoxigenin-labelled probe derived from a internal coding region of the ure $C$ gene of $P$. damselae subsp. damselae (accession number U40071). Lanes: A1 to A10, P. damselae subsp. piscicida strains; $\mathrm{B} 1$ to $\mathrm{B} 10$ and $\mathrm{C} 1$ to $\mathrm{C} 6, P$. damselae subsp. damselae strains; C7, P. histaminum; C8 and C9, negative controls (PBS and 16S rRNA gene amplification product, respectively): C10, no sample

As PCR misamplification and/or mismatches in the priming sites could have prevented the ureC gene from being amplified in Photobacterium damselae subsp. piscicida strains, a hybridization was performed with an ureC gene digoxigenin-labelled DNA probe in order to corroborate the subspecies-specific occurrence of the urease gene within $P$. damselae strains. As illustrated in Fig. 3, positive hybridization was obtained for all the subsp. damselae strains tested, whereas no subsp. piscicida isolate reacted with the ure $C$ gene probe. These results clearly demonstrate the absence of the ureC gene in $P$. damselae subsp piscicida.

Its is interesting to note that the Photobacterium histaminum reference strain showed the same PCR amplification pattern as all the $P$. damselae subsp. damselae isolates (Table 1; Fig. 2B, Lane 1), and also showed positive reaction in the hybridization experiments with the ureC probe (Fig. 3)

\section{DISCUSSION}

The inclusion of the causative agent of fish pasteurellosis within the genus Photobacterium, and the sharing of species level with $P$. damselae subsp damselae implies that any molecular tool intended to serve as a diagnosis procedure for fish pasteurellosis must be tested with an array of strains of these subspecies, in order to make sure that no cross-reaction occurs. Though 16S rRNA genes have been widely used as a target for PCR-based detection procedures of an important number of fish pathogens (Magnússon et al. 1994, Toyama et al. 1994, Hiney \& Smith 1998, Gibello et al. 1999), in the case of fish pasteurellosis there is a linitation imposed by the total homology at the 16S rRNA gene sequence level found between $P$. damselae subsp. piscicida and $P$. damselae subsp. damselae (Gauthier et al. 1995, Osorio et al. 1999). Promising approaches, based either on DNA fragments from a $P$. damselae subsp. piscicida DNA library (Zhao
\& Aoki 1989, Aoki et al. 1995) or on plasmid sequences (Aoki et al. 1997), have been reported for detection of this fish pathogen. However, we have recently noted the failure of these methods to detect all the possible isolates of the causative agent of fish pasteurellosis and/or to discriminate between $P$. damselae subsp. piscicida and subsp. damselae strains (Osorio 1998). This can be explained by the fact that when some of these methods were designed, the causative agent of pasteurellosis disease was considered within the family Pasteurellaceae and, hence, no strains of $P$. damselae subsp. damselae were included as controls in the specificity experiments.

One of the phenotypical traits shown to be characteristic of Photobacterium damselae subsp. damselae isolates as opposed to subsp. piscicida is the ability to hydrolize urea. Though rarely occurring within the Vibrionaceae, urease genes are present in several species of both Vibrio and Photobacterium. Ureases from Gram-negative bacteria are reported to contain 3 nonidentical subunits (average 70,11 and $9 \mathrm{kDa}$ ) (Mobley et al. 1995). Using conserved regions of the ureC gene from Proteus mirabilis (GenBank database accession No. U40071), an internal fragment of this gene in $P$. damselae subsp. damselae was amplified and sequenced. Taking this information together with our previous exhaustive knowledge of the $16 \mathrm{~S}$ rRNA gene sequence of a large number of $P$. damselae isolates (Osorio et al. 1999), we designed a multiplex PCR protocol which allowed us to discriminate, in a single step, $P$. damselae subsp. piscicida from any of the other bacterial species that may occur in fish or seawater.

As the $16 \mathrm{~S}$ rRNA gene belongs to a multigenic family in Vibrionaceae, the amplification product of this gene is normally more intense than the one obtained for the ure $C$ gene, which, to the best of our knowledge, is a single-copy gene. In previous work, it was demonstrated that $16 \mathrm{~S}$ rRNA gene primers can be used to detect as little as $1 \mathrm{pg}$ to $10 \mathrm{fg}$ of Photobacterium damselae purified DNA (Osorio et al. 1999). Nevertheless, the sensitivity of the multiplex PCR should not be 
affected by the difference in gene copy numbers, since very good results and low detection levels are usually obtained for other fish pathogens when a single-copy gene is used as a target for PCR (Brown et al. 1994).

In addition, the multiplex PCR and hybridization assays performed in this study firmly demonstrated that the inability of Photobacterium damselae subsp. piscicida to hydrolyze urea is due to the lack of the ure $C$ gene in its genome, and not to any inactivating mechanism for this gene. The possibility of the ureC gene being plasmid-borne can be ruled out since no plasmid DNA is present in some of the $P$. damselae subsp. damselae strains used in this work (Cutter \& Kreger 1990, Fouz et al. 1992). Although at the moment this multiplex protocol has been tested only with pure cultures of the 2 subspecies of $P$. damselae, the subspecies-specific occurrence of the urease gene opens a door to further studies focused on diagnosis procedures based on PCR and/or DNA probes that can be applied directly to fish tissues.

The astonishing degree of similarity between these 3 taxa (both subspecies of Photobacterium damselae and $P$. histaminum), as revealed by sequencing of $16 \mathrm{~S}$ rRNA gene as well as other DNA regions, indicates the need to reevaluate the taxonomy of the genus Photobacterium. In the concrete case of $P$. histaminum, the near total identity with $P$. damselae subsp. damselae in $16 \mathrm{~S}$ and 5 S rRNA, ureC, gyrB and other genes (Osorio et al. 1998, and unpubl. data) raises the question of its possible reclassification as $P$. damselae subsp. histaminum.

The results also point out the idea that one of the steps in Photobacterium damselae speciation process may include gain/loss events associated with the ure operon. This raises new questions as to how 2 subspecies related so closely at the ribosomal operon level have diverged so dramatically in certain phenotypic characters.

Acknowledgements. This work was supported in part by Grants XUGA 20003A96 from the Consellería de Educación. Xunta de Galicia and MAR99-0478 from the Ministerio de Educación y Cultura (Spain). C.R.O. thanks the Ministerio de Educación y Cultura (Spain) for a research fellowship. The authors are indebted to the donors for kindly supplying the strains.

\section{LITERATURE CITED}

Aoki T, Hirono I. Hayashi A (1995) The fish-pathogenic bacterium Pasteurella piscicida detected by the polymerase chain reaction (PCR). In: Shariff $M$, Arthur JR, Subasinghe RP (eds) Diseases in Asian aquaculture. Fish Health Section, Asian Fisheries Society, Manila, p 347-353

Aoki T, Ikeda D, Katagiri T, Hirono I (1997) Rapid detection

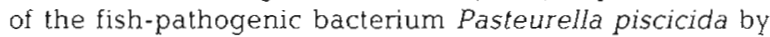
polymerase chain reaction targetting nucleotide sequences of the species-specific plasmid pZP1. Fish Pathol 32:143-151
Brown LL, Iwama GK, Evelyn TPT, Nelson WS, Levine RP (1994) Use of the polymerase chain reaction (PCR) to detect DNA from Renibacterium salmoninarum within individual salmonid eggs. Dis Aquat Org 18:165-171

Cutter DL, Kreger AS (1990) Cloning and expression of the damselysin gene from Vibrio damselae. Infect Immun 58: $266-268$

Dasen G, Smutny J, Teuber M, Meile L (1998) Classification and identification of propionibacteria based on ribosomal RNA genes and PCR. System Appl Microbiol 21:251-259

Fouz B, Larsen JL, Nielsen B, Barja JL, Toranzo AE (1992) Characterization of Vibrio damsela strains isolated from turbot Scophthalmus maximus in Spain. Dis Aquat Org 12 : $155-166$

Gauthier G, Lafay B, Ruimy R, Breittmayer V, Nicolas JL, Gauthier M, Christen R (1995) Small-subunit rRNA sequences and whole DNA relatedness concur for the reassignment of Pasteurella piscicida (Snieszko et al.) Janssen and Surgalla to the genus Photobacterium as Photobacterium damsela subsp. piscicida comb. nov. Int J Syst Bacteriol 45:139-144

Gibello A, Blanco MM, Moreno MA, Cutuli MT, Domenech A, Domínguez L, Fernández-Garayzábal JF (1999) Development of a PCR assay for detection of Yersinia ruckeri in tissues of inoculated and naturally infected trout. Appl Environ Microbiol 65:346-350

Hiney M. Smith P (1998) DNA-based diagnostics in aquaculture: can we overcome the problems of interpretation in the field. In: Barnes AC, Davidson GA, Hiney MP, MCIntosh $D$ (eds) Methodology in fish diseases research. Fisheries Research Services, Aberdeen, p 143-160

Kusuda R, Salati F (1993) Major bacterial diseases affecting mariculture in Japan. Annu Rev Fish Dis 3:69-85

Lawson PA, Gharbia SF, Shah HN, Clark DJ (1989) Recognition of Fusobacterium nucleation subgroups Fn-1, Fn-2, and $\mathrm{Fn}-3$ by ribosomal RNA gene restriction patterns. FEMS Microbiol Lett 65:41-46

Lucchini F, Kmet V, Cesena C, Coppi L, Bottazzi V, Morelli L (1998) Specific detection of a probiotic Lactobacillus strain in faecal samples by using multiplex PCR. FEMS Microbiol Lett 158:273-278

Magariños B, Romalde JL, Bandín I, Fouz B, Toranzo AE (1992) Phenotypic, antigenic and molecular characterization of Pasteurella piscicida strains isolated from fish. Appl Environ Microbiol 58:3316-3322

Magarinos B, Toranzo AE, Romalde JL (1996) Phenotypic and pathobiological characteristics of Pasteurella piscicida. Annu Rev Fish Dis 6:41-64

Magnússon $\mathrm{HB}$, Frigjórnsson $\mathrm{OH}$, Andrésson OS, Benediksdóttir E, Gudmundsdóttir S, Andrésdóttir V (1994) Renibacterium salmoninarum, the causative agent of bacterial kidney disease in slamonid fish, detected by nested reverse transcription-PCR of $16 \mathrm{~S}$ rRNA sequences. Appl Environ Microbiol 60:4580-4583

Mobloy HIT, !s!and MD. Hausinger RP (1995) Molecular biology of microbial ureases. Microbiol Rev 59:451-480

Okuzumi M. Hiraishi A, Kobayashi T, Fujii T (1994) Photobacterium histaminum sp. nov., a histamine-producing marine bacterium. Int J Syst Bacteriol 44:631-636

Osorio CR (1.998) Análisis genético de Photobacterium damselae por secuenciación del rDNA 16S. Master thesis, University of Santiago de Compostela

Osorio CR, Hutson RA, Barja JL, Collins MD, Romalde JL (1998) Análisis de regiones genómicas alternativas al rRNA 16 S para estudios taxonómicos del patógeno Photobacterium damselae. In: Abstracts of the VIII Reunion del Grupo de Taxonomía, Filogenia y Biodiversidad de la 
Sociedad Española de Microbiología, Palma de Mallorca Osorio CR, Collins MD, Toranzo AE, Barja JL, Romalde JL (1999) 16S IRNA gene sequence analysis of Photobacterium damselae and nested PCR method for rapid detection of the causative agent of fish pasteurellosis. Appl Environ Microbiol 65:2942-2946

Romalde JL, Magariños B (1997) Immunization with bacterial antigens: pasteurellosis. In: Gudding R, Lillehaug A, Midtling PJ, Brown F (eds) Fish vaccinology. Development in Biological Standardization, Vol 90. Karger, Basel, p 167-177

Editorial responsibility: Carey Cunningham,

Aberdeen, Scotland, UK
Snieszko SF, Bullock GL, Hollis E, Boone JG (1964) Pasteurella sp. from an epizootic of white perch (Roccus americanus) in Chesapeake Bay tidewater areas. J Bacteriol 88:1814-1815

Toyama T, Kita-Tsukamoto K, Wakabayashi H (1994) Identification of Cytophaga psycrophila by PCR targeted $16 \mathrm{~S}$ ribosomal RNA. Fish Pathol 29:271-275

Zhao J, Aoki T (1989) A specific DNA hybridization probe for detection of Pasteurella piscicida. Dis Aquat Org 7: $203-210$

Submitted: December 2, 1999; Accepted: January 26, 2000 Proofs received from author(s): March 28, 2000 